\title{
The Impact Of Law On The Practice Of Early Marriage In The District Of West Bangkala, Jeneponto Regency
}

\author{
Auliah Andika Rukman ${ }^{1)}$, Andi Sugiati ${ }^{2)}$, Nur Susanti ${ }^{3)}$ \\ Program Studi Pendidikan Pancasila dan Kewarganegaraan Fakultas Keguruan dan Ilmu Pendidikan \\ Universitas Muhammadiyah Makassar, Indonesia 1,2,3,4) \\ auliahandikarukman@unismuh.ac.id ${ }^{1)}$, andisugiati@unismuh.ac.id ${ }^{2)}$, nursusanti@unismuh.ac.id ${ }^{3)}$,
}

\begin{abstract}
District, Jeneponto Regency. This type of research is qualitative, to collect data, research using interview techniques, observation, and documentation. The data analysis technique used was data reduction, data presentation, and conclusion drawing. Based on the results of the study, it can be concluded that the legal impact on the practice of early childhood marriage in Bangkala Barat Subdistrict, Jeneponto Regency, is the impact of the law. A child's birth certificate does not guarantee the rights of the child/offspring. It cannot take care of other important documents such as passports, birth certificates, identity cards, health, education, and family cards. And the other impact is psychological as for the legality solution for married couples at an early age and are old enough to do the marriage ceremony in the Jeneponto religious court. This isbat aims to validate the marriage of married couples at an early age who do not have a marriage book or marriage certificate. With the marriage ceremony held in the Jeneponto religious court, the couple has legal and legal status legally.
\end{abstract}

Keywords: Legal Impact, Early Age Marriage.

\begin{abstract}
Abstrak. Penelitian ini bertujuan untuk mengetahui Dampak hukum terhadap praktek perkawinan usia dini di Kecamatan Bangkala Barat Kabupaten Jeneponto, untuk mengetahui Solusi legalitas terhadap mereka yang melakukan perkawinan usia dini di Kecamatan Bangkala Barat Kabupaten Jeneponto. Jenis penelitian ini adalah kualitatif, untuk mengumpulkan data, penelitian mengunakan teknik wawancara, observasi, dan dokumentasi. Teknik analisis data yang digunakan adalah reduksi data, penyajian data, dan penarikan kesimpulan. Berdasarkan hasil penelitian dapat disimpulkan bahwa Dampak hukum terhadap praktek perkawinan usia dini di Kecamatan Bangkala Barat Kabupaten Jeneponto yaitu dampak Hukum Tidak ada bukti otentik perkawinan yang sah, tidak adanya jaminan dan kepastian hukum, Tidak menjamin hak-hak waris, Tidak dapat membuat akta kelahiran/akta kenal lahir anak, tidak menjamin hak-hak anak/keturunan, dan Tidak dapat mengurus dokumen penting lainnya seperti Paspor, Akta Kelahiran, Kartu Tanda Penduduk, Kesehatan, Pendidikan, dan Kartu Keluarga. dan dampak lainnya adalah dampak psikologis. Adapun solusi legalitas bagi pasangan yang melakukan perkawinan usia dini dan telah cukup umur dapat melakukan itsbat nikah di pengadilan agama jeneponto. Isbat ini bertujuan untuk mengesahkan perkawinan pasangan yang kawin diusia dini yang belum memiliki buku nikah atau akta nikah. dengan diadakannya isbat nikah di pengadilan agama jeneponto pasangan tersebut memiliki status yang sah dan legal secara hukum.
\end{abstract}

Kata Kunci: Dampak Hukum, Perkawinan Usia Dini. 


\section{INTRODUCTION}

Every human being, in general, would want to have a life partner to produce offspring so that there is a marriage in this case. The Republic of Indonesia is based on Pancasila, where the first precept is Belief in One Supreme God. Marriage is considered to have a very close relationship with religion and applicable law. This means that marriage does not just happen but is carried out in a civilized manner according to God's teachings to humans. So that marriage not only has an external/physical element, but an inner/spiritual element also has a very important role in forming a happy family.

Marriage is a bond of agreement that gives birth to a family as one of the elements of life regulated by the Rule of Law, both Islamic Law, and positive law. Before the birth of the law governing marriage, it was generally regulated according to the laws of each religion and custom. However, currently, the law regulating marriage is contained in Law Number 16 of 2019 (Amendment to Law Number 1 of 1974 Article (1) Regarding Marriage). "Marriage is an inner and outer bond between a man and a woman as husband and wife to form a happy and eternal family (household) based on the One Godhead."

Garrison (1956) states that the sexual drive in adolescence is quite strong. So it is necessary to be prepared steadily about matters related to marriage because these problems underlie their thinking to start determining their life partner. Early marriage in ancient times until today is still a lot going on. This is because people have a lack of understanding/thinking about education and the Marriage Law, which has set the conditions regarding the age limit to be able to do marriage (requirements for marriage). material), one of which is the age limit contained in Article 7 paragraph (1) of Law Number 16 of 2019 (Amendment to Law Number 1 of 1974), which states that "Marriage is only permitted if a man and woman have reached the age of 19 years. "

The reality is that what happens in the community is that the requirements above are only a formality. Many of them do early marriage because they like each other, economy, education, parental coercion and other problems. This is because people do not know the impact of early marriage in the future. After all, it is too soon to marry off their children. But sometimes parents who have daughters are more likely to marry off their daughters because they think that the older the daughter is, the more gossip from the community, even for some people who say that a girl who has passed 20 years and has not been married can be called a spinster.

From this habit, some parents immediately marry off their children even though the child is still in school so that education that should be continued is put aside. The registration of marriages that have been stipulated in the law aims to make marriages 
administratively orderly. Therefore unregistered marriages are contrary to the provisions stipulated by law. So that the marriage has no legal force and legal protection from a country, this does not mean that the marriage is invalid, but if there are parties who are harmed, they cannot obtain their rights and other protections from the government. In fact, what is happening now is that some people do underage marriages, so that the purpose of marriage itself is not realized. Underage marriages are commonplace in society. This is because it is driven by tradition in a society so that there is a desire to speed up the marriage.

Therefore, the researcher chose the title that will be studied because there are still many marriages that occur because of some of the impacts found from early marriage, especially the impact of education, law, health, and psychology. Based on the problems above, the researcher is interested in researching with the title "The Impact of Law on the Practice of Early Marriage in the District of West Bangkala, Jeneponto Regency

\section{RESEARCH METHODS}

The type of research was a qualitative research type with a descriptive approach. Qualitative research is a research procedure that produces descriptive data in written or spoken words from people and observable behavior (Bagdan and Taylor: 1955). The location of this research was carried out in the
District of West Bangkala, Jeneponto Regency. This research was carried out for 2 months. There were two sources of data used, namely primary data sources and secondary data sources. The informants in this study consisted of two main informants and ordinary informants. The discovery of the main informants in this study was selected by purposive sampling, and the findings of the informants were usually selected by snowball sampling (Sugiyono, 2009: 292). The determination of regular informants was still temporary and will develop later after researchers were in the field. Sources of data in the early stages of entering the field, researchers selected people who had power and authority on the object under study to provide a way for researchers to collect various data found as for how to obtain data that was in accordance with the problems in the research to be carried out, where the researcher acts as a planner and as an executor of the research design which had been prepared.

Several data collection techniques were used in this study, namely (1) Observation techniques. The things observed were matters related to the legal impact on the practice of early marriage in West Bangkala District, Jeneponto Regency. (2) Interview/interview technique, used in this study to collect data which was done face-to-face directly so that the data obtained were in accordance with what was conveyed by the subject. The conversation during the interview/interview 
was recorded or written to get valid data. (3) Documentation, in this case, in the form of an important picture of the research that was carried out in the District of West Bangkala, Jeneponto Regency. Data collection, data reduction, data presentation, and drawing conclusions or data verification flows were used to analyze the data, steps, or flows that occurred simultaneously (Milles, 2002: 1519).

\section{DISCUSSION}

Impact of Law on the practice of Early Marriage

According to the provisions of Law Number 16 of 2019 (Amendment to Law Number 1 of 1974 concerning marriage), the age limit contained in article 7 paragraph (1) "Marriage is only permitted if a man and woman have reached the age of 19 years" (Law -Law Number 16 of 2019 concerning Marriage).

However, many parents marry their children who are not old enough because they are pregnant, love each other, and because of their parents. Lack of understanding of Law Number 16 of 2019 (Amendment to Law Number 1 of 1974 concerning marriage) so that the community, parents, especially couples, do not understand the consequences and impacts of marriage. Moreover, those who marry without obtaining a marriage dispensation permit to the religious court after being given a rejection letter from the KUA as a result, legally, their marriage is illegal. So that there are violations of 3 laws, namely Law Number 16 of 2019 article 7 paragraph (1) "Marriage is only permitted if a man and woman have reached 19 years". Article 6 paragraph (2) "To carry out a marriage, a person who has not reached the age of 21 years and must obtain permission from both parents" (Law Number 16 of 2019 concerning Marriage).

"Law Number 23 of 2002 concerning child protection, article 26 paragraph (1) "Parents are obliged and responsible for:

1. Nurturing, nurturing, educating, and protecting children.

2. Develop children according to their abilities, talents, and interests.

3. Prevent marriage at the age of children.

4. Law on PTPPO (Eradication of the Criminal Act of Trafficking in Persons) This law aims to protect children so that children continue to obtain their rights to live, grow and develop and are protected from acts of violence, exploitation, and discrimination" (Law Number 23 Year 2002 on child protection).

The study results in West Bangkala District, Jeneponto Regency, showed that couples who married at an early age did not take care of the administration after they married. Many couples want to take care of family cards and birth certificates for their children. Still, they do not have authentic proof of a valid marriage, namely a marriage book, 
until now. Hence, there is no legal guarantee or legal certainty for couples who have married early and do not guarantee one day if the couple Having children does not guarantee their inheritance rights. The couple only realized how important the marriage book was after they got married so that the legal impact felt by couples who had an early marriage in the West Bangkala sub-district, Jeneponto Regency, was unable to take care of important documents such as:

1. Passport

2. Birth Certificate

3. Identity Card (KTP)

4. Health

5. Family Card (KK)

6. Education

Conducting early marriage is strictly prohibited and can violate the marriage law and impact couples who have married at an early age, especially their children. However, there are still many marriages that asking for a marriage dispensation granted by the religious court. Some do not have a marriage dispensation permit and continue to marry at an early age.

Another impact is the child's psychology because psychologically, the child is also not ready and does not understand sex. It will cause prolonged psychological trauma in the child's psyche, which may not have healed. Seen from his changed habits, children are often moody, regretting his life which ended in a marriage that he did not understand.
Besides that, the most important impact is that the child will feel that he has lost his right to proper education, the right to play and enjoy his free time, and the rights inherent in the child. In the Child Protection Law Number 23 of 2002 Article 9 also explains that every child has the right to receive education and teaching in personal development and the level of intelligence according to his interests and talents.

\section{Legal Solutions for Those Who Do Early} Marriage

The number of early marriages continues to increase. There is no legal guarantee for couples who marry early if they do not have a marriage book or marriage certificate. From the results of the description that researchers have described the impact caused by the existence of early marriage in the West Bangkala District, Jeneponto Regency, as for legal solutions that can be carried out by couples who carry out early marriage, among others.

With the policy from the government and the issuance of a marriage dispensation permit policy for those who are not old enough and will do early marriage, the number of marriages is increasing. Therefore, the Jeneponto Religious Court provides a legal solution for couples who have married early and are old enough to perform isbat marriage at the Jeneponto Religious Court. This purpose is to ratify the marriage of couples who marry 
at an early age who do not yet have a marriage book or marriage certificate. With the Isbat Marriage holding at the Jeneponto Religious Court, the couple has legal and legal status. To perform isbat marriage, the couple must meet several requirements.

The conditions that early marriage couples must meet to perform isbat marriage are as follows:

1. Submit an application for marriage certificate to the local religious court.

2. A certificate from the local office of religious affairs (KUA) stating that the marriage has not been registered.

3. Certificate from the village head explaining that the applicant has married.

4. Photocopy of the marriage applicant's ID card

5. Pay court fee

6. Others to be determined by the judge in the trial"

In accordance with the formulation of Article 7 paragraph 3 isbat marriage compilation of Islamic law, which reads, "Isbat marriage can be submitted to a limited religious court on matters relating to:

1. The existence of marriage in the context of the divorce settlement

2. Loss of marriage certificate or marriage book

3. There are doubts about whether or not one of the conditions of marriage is valid
4. The existence of a marriage that occurred before enacting Law Number 16 of 2019 (amendment to Law Number 1 of 1974).

5. Marriages carried out by those who have no marital barriers according to Law Number 16 of 2019 (amendment to Law Number 1 of 1974)" (Source: Jeneponto Religious Court).

Therefore, it is important for couples in West Bangkala Sub-district, Jeneponto Regency to arrange marriages in a religious court for those who have married early.

\section{CONCLUSION}

Based on the results of the research that has been described previously, the researcher can conclude that:

1. As for the legal impact on couples who engage in early marriage in Bangkala Barat District, Jeneponto Regency, namely: There is no authentic evidence of a valid marriage, there is no guarantee and legal certainty, Does not guarantee inheritance rights, Can't make a birth certificate/certificate of identification birth of a child, Does not guarantee the rights of children/offspring, Cannot take care of important documents such as Passport, Birth Certificate, Identity Card (KTP), Health, Family Card (KK), Education. Another impact is psychological.

2. Legal Solutions for Those Who Do Early Marriage in West Bangkala District, Jeneponto Regency. The Jeneponto 
Religious Court provides legal solutions for couples who marry early and are old enough to get married at Jeneponto Religious Court. This Isbat aims to ratify the marriage of couples who marry at an early age who do not have a marriage book or marriage certificate. With the marriage at the Jeneponto Religious Court, the couple has legal and legal status.

\section{REFERENCES}

[1] Abdul Kadir Muhammad. (2014). Hukum Perdata Indonesia. Bandung: PT Citra Aditya Bakti.

[2] Albi Alggito Dan Johan setiawan. (2018). Penelitian Kualitatif. Jawa Barat:CV Jejak.

[3] Amir Syarifuddin. (2003). Gari-Garis Besar Fiqih. Bogor: Kencana.

[4] Firdaus dan Fakhry ZamZam. (2018) Metodologi Penelitian. Deepublish.

[5] Hanafi Arif. (2016). Pengantar Hukum Indonesia. Yogyakarta: Lkis Pelangi Aksara

[6] Ismail Nurdin dan Sri Hartati. (2019). Metodologi Penelitian Sosial. Surabaya: Media Sahabat Cendekia.

[7] Khoiruddin Nasution. (2002) Status Wanita Di Asia Tenggara. Jakarta:Leiden

[8] M, Ali Hasan. (2003). Pedoman Hidup Berumah Tangga Dalam Islam. Jakarta:Siraja

[9] Muhammad Makmum Abha. (2015). Benarkah Aisyah Mekawin Di Usia 9 Tahun. Jakarta: Buku Seru.

[10] Mardi Candra. (2018). Aspek Perlindungan Anak Indonesia. Jakarta Timur: Prenada Media Group.

[1] Milles, MB \& Hubberman. AM (2002). Analisis data kualitatif. Terjemahan oleh Tjetjep Rohidi dan Mulyarto, Jakarta: UI Percetakan.
[11] M. Zamroni. (2019). Prinsip-Prinsip Hukum Pencatatan Perkawinan di Indonesia. Surabaya: Media Sahabat Cendekia.

[12] Sudarsono. (1991). Hukum Kekeluargaan Nasional. Jakarta: Rineka Cipta

[13] Simajuntak. (2017). Hukum Perdata Indonesia. Jakarta: Kencana.

[14] Sulistyowati. (2006) Perempuan Dan Hukum:Menuju Hukum Yang Berspektif Kesetaraan Dan Keadilan.: Yayasan Obor Indonesia.

[15] Sarlito Wirawan Sarwono. (2005). Psikologi Remaja. Jakarta: PT. Raja Grafindo Persada.

[16] Suzie Sugijakanto. (2014). Cegah Kekerasan Pada Anak. Jakarta: PT Elex Media Komputindo.

[17] Wayang Suwendra. (2018). Metode Penelitian Kualitatif. Bali: Nila Cakra.

[18] Wahyono Darmabrata. (2003). Tinjauan Undang-Undang Nomor 16 Tahun 2019 Tentang Perkawinan Beserta UndangUndang dan Peraturan Pelaksanaannya, cet.ke-2, CV.Gitamaya Jaya

[19] Nurhidayatullah dan leni Marlina. (2011) Perkawinan di Bawah Umur Perspektif HAM“ dalam jurnal Al-Mawarid, Volume XI, nomor 2, tahun 2011 “, Pusa Penelitian Magister Hukum FH UII Yogyakarta.

[20] Zulviani. (2017) Kajian Hukum Terhadap Perkawinan Anak Di Bawah Umur Menurut Undang-Undang Nomor 1 Tahun 1974 "dalam jurnal hukum samudra keadilan, Volume XII, no 2, tahun 2017”, Pusat Penelitian Fakultas Hukum Universitas samudra, Maurendeh, langsa aceh.

[21] Marmiati Mawardi. (2012) Problematika Perkawinan di Bawah Umur "dalam jurnal Analisa, Volume IXI, no 2, tahun 2012", Pusat Penelitian Balai Penelitian dan Pengembangan Agama, Semarang.

[22] Eka Yuli Handayani. (2014) Faktor-Faktor Yang Berhubungan Dengan Perkawinan Usia Dini Pada Remaja Di Kecamatan Tambusai Utara Kabupaten Rokan "dalam jurnal maternity and neonatal, Volume 1, no 5 tahun 
2014". Pusat Penelitian Universitas Pasir Pangaraian,Riau.

[23] Ilham Laman. (2017). Perkawinan di Bawah Umur di Kelurahan Purangi. Makassar. Universitas Negeri Makassar.

[24] Undang-Undang Republik Indonesia Nomor 16 Tahun 2019 Tentang Perkawinan, Bandung, Citra Umbara. 